\title{
The role of politics in sustainable transitions: The rise and decline of offshore wind in Norway
}

\section{Håkon Endresen Normann}

TIK Centre for Technology, Innovation and Culture (TIK), University of Oslo

Published in Environmental Innovation and Societal Transitions. Volume 15, June 2015, 180-93

\begin{abstract}
This paper studies how political conditions and external events influenced the rise and fall of offshore wind on the political agenda in Norway between 2005 and 2012. In this sense, the paper contributes to recent debates about the role of politics in sustainable transitions. Key findings are that changes in government posts combined with a need for the offshore petroleum industry to diversify created favourable conditions for offshore wind. However, offshore wind as a solution to articulated problems was insufficiently developed when the window of opportunity opened up. The analysis then shows how a recovery in the offshore petroleum industry and new changes inside government closed the window of opportunity. The paper concludes that we should attend more to the interests of government actors, and conflicts inside government, in the analysis of energy transitions.
\end{abstract}

Keywords: Agenda setting, Offshore wind energy, Policy, Politics, Sustainable transitions 


\section{Introduction}

Studies of sustainable transitions seek to understand how the introduction and development of more renewable energy technologies can be promoted. Since many of these technologies are immature, the introduction of technology-specific policies that protect these technologies from competition is often necessary (Sanden \& Azar 2005). Because different technologies require different types of policy intervention, a growing body of literature has employed a technological innovation system (TIS) framework to help identify barriers for technology development, which then can be used to design technology-specific policies (Hekkert et al. 2007; Jacobsson \& Bergek 2011). A related approach focuses on the need to nurture immature innovations through strategic niche management (Kemp, Schot, \& Hoogma 1998). Both approaches recognise the importance of technology-specific policies for technology development. However, overly attention to the effects of policy on technology development can lead to a neglect of the political processes that bring about policy change. In recent years there has therefore been an increased attention in the transitions literature to the formation of policy (Weber \& Rohracher 2012, p. 1040). An emphasis on niche empowerment (Smith \& Raven 2012, p. 1030), or the strengthening of the process of legitimation in the innovation system (Jacobsson \& Lauber 2006), does provide opportunities to study influences on the policy-making process. However, much analysis has still tended to neglect the political circumstances that make the adoption of certain policies likely (Meadowcroft 2011, p. 73). Because a successful transformation of e.g. the electricity system is not only about a technological but also a political challenge (Kern 2010, p. 20), studies of transition processes therefore need to put more emphasis on the role of politics and the complexity of the policy formation process (Flanagan, Uyarra, \& Laranja 2011, p. 704; Jacobsson \& Bergek 2011, p. 55).

This paper seeks to explore the role of politics in transition processes by analysing attempts to secure public support for the introduction of policies for offshore wind in Norway. On the one hand, Norway has the potential to contribute significantly through its impressive offshore wind resources (Energirådet 2008) and technological competencies related to the offshore oil and gas (O\&G) industry (Steen \& Hansen 2013). On the other hand, an electricity sector dominated by hydropower and a reliance on cost-efficient policy measures has provided few opportunities for immature energy technologies over the past two decades. Nonetheless, between 2007 and 2009, the government signalled that it had big ambitions for offshore wind in Norway, hence leading to large public and industrial R\&D initiatives. Despite the political ambitions for the development of offshore wind, coupled with substantial private and public investments, only 2.3 MW of capacity has so far been constructed off the Norwegian coast. The empirical objective is to study how offshore wind could rise so prominently on the agenda in Norway and why the big ambitions for the development of offshore wind have not been realised. In this way, the main justification for the study is to shed more light on the political processes exerting an influence on the development of renewable energy technologies. 
In the following section, I provide a brief review of how the development of niche technologies can be studied with a theoretical point of departure in the sustainable transitions literature. Here, I propose an agenda-setting model as a useful framework for providing a better understanding of the role of politics and agency in the development of renewable energy technologies. Section three presents the agendasetting model in more detail. In section four, I trace the development of offshore wind in Norway, with an emphasis on political and industrial events. Using the framework presented in section three, I distinguish between different periods in the agenda-setting process, and outline how this may explain what can broadly be called "the rise and fall" of offshore wind development in Norway. Section five sums up the findings and proposes some implications for further research.

\section{Theoretical background: Understanding the development of niche technologies}

From ideas of path-dependency and carbon lock-in (Unruh 2000), we know that established technologies often hold many advantages over new technologies. An important contribution in the literature on sustainable transitions has therefore been made by exploring how the creation of protective markets and technology-specific policies for new renewable energy technologies such as offshore wind (e.g. Kern et al. 2014) can counteract the effects of path-dependency and lock-in. With the attention to policies comes the need to understand how policies are shaped. Simply put, policies are shaped through negotiations between both interested state and non-state actors (Smith, Stirling, \& Berkhout 2005). Actors have different opportunities to negotiate the policy process (Smith \& Raven 2012, p. 1031), and these opportunities are influenced by the institutional environment (Jacobsson \& Lauber 2006). This asymmetrical distribution of opportunities is often self-reinforcing through positive feedback processes.

The concept of regimes can be useful for understanding the role of path-dependency and how new paths can be created (Hanson 2013). Although there is little coherence in the literature on the regime concept (Markard \& Truffer 2008, p. 605), one common interpretation is that regimes provide stability, consequently acting as a barrier for the development of new technologies. A main purpose of the multilevel perspective (MLP) on transition processes has been to show how regimes can be unlocked through pressure on the regime from the development of alternative niche technologies and exogenous developments occurring at the 'landscape' level. A destabilisation of the regime can then open a window of opportunity for advocates of niche technologies to help influence the policy process (Geels \& Schot 2007, p. 400). Geels and Schot (2007) stress that the timing of exogenous events and the development of niche technologies are of great importance. For instance, the maturity of niche technologies when external pressure is applied to the regime will greatly impact on the ability of advocates of these technologies to exploit opportunity windows. 
The MLP provides a heuristic device to understand how regimes may change through the articulation of windows of opportunity (Geels 2011). However, this perspective rarely explains why such opportunities are created, how interested actors negotiate these opportunities and why opportunity windows close (Smith, Voß, \& Grin 2010, pp. 445-6). In particular, the perspective has been criticised for not providing a sufficient understanding of the political circumstances for policy formation (Meadowcroft 2011) and for not incorporating a conceptualisation of power (Avelino \& Rotmans 2009; Smith et al. 2005). However, an excessive emphasis on power may put us in danger of downplaying the role of institutions and structures in facilitating and constraining the negotiations between different interests (Hill 2013). In recognition of this, approaches focusing on policy networks (Marsh \& Rhodes 1992) or advocacy coalitions (Sabatier \& Jenkins-Smith 1993) have been developed as a way of conceptualising the role of power and institutions in the analysis of the policy process. Attending to the role of advocacy coalitions, Kern et al. (2013) find that studying how actor networks create narratives to draw attention to particular solutions can explain why some sustainable energy advocates are more successful than others in influencing policy. However, they also conclude that their proposed framework pays insufficient attention to how competing issues on the agenda as well as competing solutions to policy problems affect the opportunities for actors or groups of actors to influence policy. I would add that the framework pays too little attention to how solutions become attached to different problems, and how this affects the position of certain solutions on the political agenda.

\section{Agenda-setting}

Borrás and Edler (2013) suggest opportunities for policy change occur through a co-evolution of technological and institutional change. However, as mentioned above, opportunities themselves do not generate change. Thus, it becomes important to study the capabilities of agents to exploit opportunities. Kingdon $(1984,2011)$ argues that such capabilities depend on the availability of appropriate problems and the agents' ability to attach policy solutions to these problems. This ability is also influenced by the prevailing political environment at the time. To comprehend how political actors operate within an institutional context, Kingdon (2011) conceives of "three policy streams flowing through the system streams of problems, policies, and politics. They are largely independent of one another, and each develops according to its own dynamics and rules. But at some critical junctures the streams are joined, and the greatest policy changes grow out of that coupling of problems, policy proposals, and politics (p. 19).” To this, Sabatier (1991, p. 151) points out that even though Kingdon developed his model primarily for studying agenda-setting and policy formulation, the model can easily be expanded to the entire policy process.

Kingdon's agenda-setting model provides a number of complementary tools to the study of politics and sustainable transitions. Hannigan (1995), who argues that struggles over policies can be 
particularly complicated when it comes to energy and climate issues, displays how Kingdon's model has been applied as a framework for explaining environmental policy outcomes. Moreover, Kingdon's focus on how the coupling of societal problems, available solutions and political conditions can lead to policy change, is reminiscent of the importance Geels and Schot (2007) place on the timing of events. This is demonstrated by Elzen et al. (2011) who show how Kingdon's model of agenda-setting can enrich the MLP by attending more explicitly to the role of agency, politics and the timing of events.

In this paper, I demonstrate that concepts from Kingdon's model can enhance our understanding of the political dynamics affecting sustainable transitions. First, the inclusion of political dimensions opens up for a greater understanding of the complexities of the policy making process. Second, Kingdon's explicit attention to the coupling of solutions to problems provides a tool for understanding how certain issues have come to dominate the political agenda. The theoretical purpose of this paper is to enrich the ideas of windows of opportunity in the transitions literature by applying Kingdon's model of agenda-setting to a renewable energy case. I do this to better understand the processes that can lead to windows of opportunity, under what circumstances such opportunity windows can be exploited, and finally, why such windows are closed.

\subsection{The policy stream}

The principal concept in the agenda-setting model is the concept of ideas. Kingdon is not interested in where these ideas come from, but rather under what circumstances they blossom (2011, p. 77). Ideas circulate in the policy stream, and can be interpreted as policy solutions or alternatives that have not necessarily been coupled with a particular problem. Thus, Kingdon uses the concepts of ideas, solutions and alternatives interchangeably, with the point of interest here being the idea of offshore wind and the actors involved in developing this idea. For this reason, the critical thing to explore in the policy stream is how offshore wind surfaced above all of the other ideas in the policy stream. The concept of a policy stream can be related to the concept of technological niches. Niches are sources of transformative ideas and capabilities, and provide 'spaces' for alternatives or solutions that are not yet competitive against the selection environment in the prevailing regime (Smith et al. 2010, pp. 440-1). By using the concept of solutions in the policy stream, we may then also understand more about why some niches are favoured over others.

Kingdon (2011) proposes several characteristics of the policy stream that may affect the selection of ideas. First, a policy alternative needs a policy entrepreneur that is persistent over time and willing to invest resources in promoting the idea (pp. 122-4). Additionally, policy alternatives are constantly evaluated against criteria such as technical feasibility, projected costs and anticipated reception among key decision makers (pp. 131-9). For a successful exploitation of an opportunity window, a policy alternative must therefore be properly developed and compatible with budgetary considerations. Nevertheless, it is through changes in the problem or political stream that certain ideas rise above the 
rest. If the conditions are not right in the political stream, or if the policy alternative is not attached to an appropriate problem, the window may only be open for a short time.

\subsection{The problem stream}

The problem stream contains all types of conditions that people in and around government could attend to at some point in time. Kingdon (2011) hence makes an important distinction between a condition and a problem. A condition can be recognised through a variety of indicators, exogenous shocks and feedback processes related to existing policy processes. However, a condition only becomes a problem when we come to believe that something can and should be done about this condition. This understanding of problems resonates with what Smith et al. (2005) term the articulation of selection pressures, which relates to whether a particular problem has been defined, as regimes are constantly exposed to different kinds of pressure. However, it is when different pressures act in concert and are explicitly translated into problems that substantive regime change can occur (ibid. , p. 1495). In this process of problem definition, the context for a transition plays a pivotal role (Hanson 2013, p. 168). Thus, when looking at the agenda-setting process we must also explore how particular problems are defined, and under what conditions offshore wind has been attached to articulated problems.

Kingdon also proposes several explanations as to why problems drop off the agenda. First, government officials may feel that they have addressed the problem by introducing new legislations. Second, a failure to solve or address a problem can lead to it dropping off the agenda due to lack of stamina from those actors that have invested in keeping the issue on the agenda.

\subsection{The political stream}

The political stream consists of both public opinion and the actions of the political elite, and has powerful effects on the articulation of conditions as problems. Kingdon (2011, pp. 153-64) argues that the type of change that has the most impact is shifts in the national mood, combined with government changes through elections and changes in government posts. While consensus in the policy stream is reached through persuasion, consensus in the political stream is reached through bargaining. This has the implication that we must explore the negotiations that occur inside government to better understand why certain issues rise on the agenda, which can be done through the analysis of public debates. However, the particular nature of the policy process offers a methodological challenge since many of the real negotiations over policy take place outside of the public eye (Hill 2013). To a certain extent, this problem can be mediated by conducting elite interviews.

\subsection{Coupling of the streams}

Windows of opportunity primarily occur through changes in the political or problem stream. Sometimes the window is opened up by a problem that presses in on the government. This is also 
recognised by Geels and Schot (2007), who emphasise that external shocks and events can open opportunities for particular niches or alternatives. To this, Kingdon (2011) adds that alternatives fare much better if there are also favourable conditions in the political stream. His main point is that windows of opportunity do not in themselves lead to change. Instead, change occurs through the coupling of a solution to a particular problem, which then makes developments in the political stream critical for the likelihood of such a coupling. An analysis that includes events in all three streams, including attention to the timing of events, will help us understand more about the role of politics in the development of new RETs.

Solutions are sometimes rather arbitrarily attached to problems, and then often inappropriately (Hovi, Underdal, \& Ward 2011). An understanding of the different problems that offshore wind has been attached to, as well as the relevance of this coupling in the broader political context, can also provide insights into the rise and fall on the agenda.

Kingdon sees the development in each stream as largely independent of changes in the others. The implication of this understanding is that what gets on the agenda depends upon fortuitous timing (Mucciaroni 1992, p. 460). This is problematic, as it neglects any element of strategic action and choice, which does not make for a particularly useful perspective for anyone interested in contributing to the development of new RETs. Mucciaroni (1992) therefore suggests an alternative that stresses the importance of linkages between the three streams, and the advocacy coalition framework (Sabatier \& Jenkins-Smith 1993) can be understood partly as an attempt to see the policy and political stream as more closely related (Kingdon 2011, p. 218). This is a sensible approach, insofar as it will tell us more about the attempted strategies (or lack of) involved in placing certain issues on the agenda. Advocates of a certain solution will make conscious efforts to attach this solution to a problem recognised in the problem stream, while political changes can simultaneously influence the articulation of different problems. By tracing the mutual interdependence between the streams, agenda-setting seems less random and more purposeful.

Kingdon's model serves a purpose by accounting for why some ideas rise on the agenda. Even so, the complexity of translating policy objectives into instructions for action poses a challenge, as ideas may nevertheless fail to influence actual policy outcomes (Hill 2013, pp. 180-204). The reason for this failure can be that the 'sellability' of an idea depends on the wider political framework (Smith 2007, p. 1444). In the analysis, I will therefore also explore some of the preferences of the different political parties in government, and how these may have affected the reception of certain ideas and solutions.

The model of agenda-setting requires a detailed tracing of events in the areas of problems, solutions and politics. Hence, I employ the method of process tracing. Process tracing is well suited for explaining particular policy outcomes (George \& Bennett 2005, pp. 205-32), in addition to being 
helpful for studying how the relationship between agency and structure influences such outcomes (Pettigrew 1997, p. 341). The main part of my empirical data consists of 27 semi-structured interviews conducted in 2013 and 2014 with politicians (7), civil servants (2), industry representatives (11), research centres (2) and interest organizations (5). On average, the interviews lasted one hour, and were recorded, transcribed and coded according to the concepts presented in the analytical framework in order to trace developments in the three streams. Newspaper archives, public documents and minutes from parliamentary debates have also been used to construct the narrative and as a way of reducing primary source bias by triangulating data (Thies 2002, p. 359).

\section{The rise and decline of offshore wind in Norway (2005 - 2012)}

In this section, I describe the development of offshore wind in Norway. However, it is first necessary to point out a few key structural conditions that have influenced the development of renewable energy in Norway. Following the deregulation of the Norwegian electricity market in 1991, Norwegian energy policies have rested on a short term cost-efficiency principle that has guided resources towards less expensive technologies for electricity production (Hanson, Kasa, \& Wicken 2011, pp. 236-9). Moreover, nearly all domestic electricity consumption is covered by emission-free hydropower. Consequently, it has been difficult to see any substantial motivation for a rapid expansion of new renewable energy in Norway (ibid.). It is also important to understand that the vast majority of Norwegian offshore wind firms have grown out of, and are still linked to, the petroleum industry (Steen \& Hansen 2013). This linkage has resulted in a competitive advantage related to marine operations and offshore technology. Nevertheless, this relationship also makes the offshore wind industry sensitive to developments in the offshore petroleum industry.

\subsection{A window of opportunity opens up (2005-2009)}

Whereas the first offshore wind farm was installed off the coast of Denmark in 1991 (EWEA 2013), concrete plans for a domestic market for offshore wind in Norway emerged in 2005 when the project development company Havgul announced plans for a large bottom fixed offshore wind park called Havsul. Motivated by energy deficits in the Møre region, caused by the development of new energy intensive industry in the region without additional investments in grid and new production capacity, the need for new electricity production was from 2005 an increasingly debated issue in Parliament (e.g. Stortinget 2006). An important driver behind Havsul was therefore to develop the project as a solution to this problem. Although the project lacked licences and funding at the time, the early plans for Havsul played an important role in planting the idea of a domestic market for offshore wind in the policy stream. At the same time as a licence application for Havsul was submitted, several of the biggest energy companies made R\&D investments in offshore wind as Statkraft, Shell and Lyse Energi, together with the Research Council of Norway, invested 1.4 million EUR in a three-year research project, using a floating concept for offshore wind developed by the company Sway. A 
further investment of 19 million EUR was then made in 2007 by Statoil, Lyse Energi, Scatec and Rosenberg Verft. In contrast to, e.g. Danish offshore wind turbines installed in shallow waters, the Sway concept used an anchor line based on existing offshore technology, and could therefore be installed in deeper waters with rougher seas. The national oil company Statoil also had its own floating turbine concept called Hywind, which had originally been developed by two engineers at the energy company Hydro. ${ }^{1}$ In 2007, Statoil received 7.5 million Euros from Enova ${ }^{2}$, a public enterprise, in support for what would be the world's first full-scale floating turbine demonstration off the Norwegian coast. Statoil initially had an agreement with the partners at the Troll natural gas and oil field to connect Hywind to petroleum installations (Strømmen Lycke 2013). However, because there was no law governing this part of the North Sea, it was not possible for the authorities to grant a licence. As a result, the project had to be moved to within $10 \mathrm{~km}$ of the shoreline, and an opportunity for niche protection through electrification of petroleum installations was missed. Lyse Energi also announced plans for a separate offshore wind project in the North Sea, and were in talks for a period with ConocoPhillips about supplying the Ekofisk oil field with electrical power from offshore wind turbines (Aamodt 2014).

Towards the end of 2007, developments in the political and problem streams opened up an opportunity for the idea of offshore wind to rise to the surface of the policy stream. First, the consequences of climate change as a condition was more explicitly articulated as a serious problem. As shown in Figure 1, public attention to climate change in 2007 was more than double that of previous and subsequent years, which was largely fuelled by the publication of the fourth assessment report by the IPCC. The increased public and media attention was amplified by pressure from the political opposition towards the government to introduce plans for new renewable energy production. With reference to Hywind, as well as the possible electrification of offshore O\&G installations, this included a proposal by the opposition to invest in offshore wind in Norway (Stortinget 2007). An important change in the political stream came when Åslaug Haga was appointed as a new Minister of Petroleum and Energy in 2007:

I'm not sure where it started, but I remember that Aslaug Haga established the Energy Council [which focused on offshore wind] (...) and I would say that the fact that Aslaug Haga entered the Ministry of Petroleum and Energy made a difference (Flataker 2013).

Haga was a renewable energy enthusiast, and she immediately commissioned a special report on the offshore wind potential in Norway. The report, which was delivered to the minister in May 2008, highlighted both industrial opportunities and the potential for clean electricity exports (Energirådet 2008). It was in particular the contribution of offshore wind as a solution to the problem of climate

\footnotetext{
${ }^{1}$ Hydro and Statoil merged in 2007.

${ }^{2}$ Enova is owned by the Ministry of Petroleum and Energy and is the main instrument for financing more efficient energy consumption and increased production of new renewable energy.
} 
change and the idea of Norway as "Europe’s green battery" that was emphasised by Haga and other members of government. These attempts to couple offshore wind as a solution to the problem of climate change seems to have been primarily driven by political rather than industrial actors.

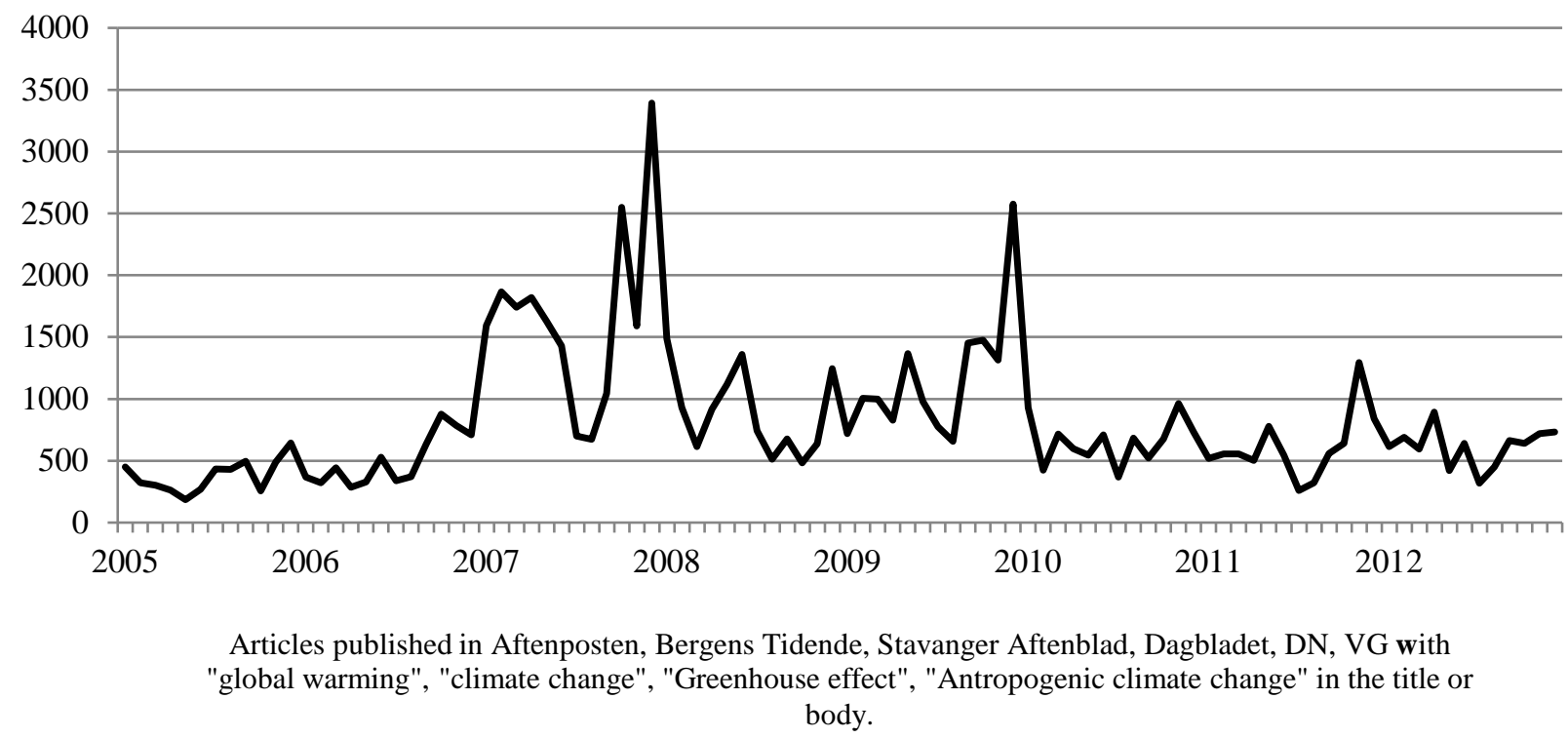

Figure 1 Attention to climate change in Norwegian media

The increased attention to climate change in both the general public and Parliament led to the negotiation of the so-called Climate Agreement towards the end of 2007. The purpose of this agreement was to ensure a long-term strategy for Norwegian climate policy that all political parties could agree upon. ${ }^{3}$ The agreement was initiated by the Liberal Party from the opposition and the Socialist Left Party from the coalition government, and was an opportunity for the opposition to raise the issue in Parliament for a need to complement policies based on a cost-efficiency principle with technology-specific policies (e.g. Stortinget 2008). An important outcome of the agreement was the establishment of eight Centres for Environment-friendly Energy Research (FME) in 2009 (Frøysa 2013). Two of these, NORCOWE and NOWITECH, targeted offshore wind. The FMEs received extensive support from the industry, though firms such as Statkraft and Vestavind Offshore argued for concentrating offshore wind research efforts in one centre. Several industry representatives pointed out in interviews that the establishment of two centres led to an unhealthy competition over researchers, funding and industrial partners.

In June 2008, Terje Riis-Johansen replaced Haga in the Ministry of Petroleum and Energy (MPE), and later in 2008 he initiated work on a new law for the production of offshore renewable energy. The adoption of the law in Parliament in 2009 improved the idea of offshore wind as a realistic alternative by removing practical barriers (Strømmen Lycke 2013).

\footnotetext{
${ }^{3}$ The Progress Party was excluded from the negotiations.
} 
A second initiative in 2009 by Riis-Johansen was to provide a licence for the Havsul project. The project, which had been purchased by the energy consortium Vestavind Offshore, would consist of 70 turbines with an installed capacity of $350 \mathrm{MW}$. The total cost of the project was estimated to approx. 900 million Euros, with about 200 million Euros needed in investment support from Enova or directly from the state (Bergens Tidende 2011). The government was still under pressure to resolve the problem of regional electricity demand. The licence was therefore presented by the government as a solution to this problem (Hjørnegård 2014), whilst Vestavind Offshore also highlighted the benefits to industry development and job creation.

We can see that in the period between 2007 and 2009, a range of developments in the political stream appeared to signal government investments in offshore wind. Both Ministers Haga and Riis-Johansen argued for public support of offshore wind, while the political opposition repeatedly attempted to put pressure on the government to invest in offshore wind. The attention to offshore wind in the Climate Agreement was influenced by these developments. Nonetheless, despite the stated political ambitions, there was an increasing unrest in the industry about the lack of financial instruments needed to realise these ambitions. The developers of Havsul responded to this by arguing publicly for improved framework conditions (e.g. Sunnmørsposten 2009). Even though these complaints were echoed by other influential energy companies such as Statoil, Statkraft, Fred. Olsen and Scatec, these firms reacted by investing in offshore wind projects in the UK market, where the incentives were more favourable. A consequence of this was that Statoil and Statkraft from an early stage showed little interest in collaborating with other Norwegian firms (Tande 2013) nor in the development of a domestic market (Dirdal 2013).

Despite promising industry developments and favourable conditions in the political stream, coupling offshore wind with the problems of both an energy deficit and climate change proved difficult. The regional energy shortage in Møre had been a critical problem for the government during the winter of 2006/2007 due to cold and dry weather. However, due in part to more rain leading to an improved hydropower production, this problem diminished in the subsequent years. Moreover, Prime Minister Stoltenberg from the Labour Party was famously known for his support of cost-efficient climate measures and technology-neutral policies (Alstadheim \& Stoltenberg 2010). With an increased appreciation of the costs of offshore wind compared to other solutions available in the policy stream such as onshore wind, small-scale hydropower and even natural gas, a coupling of offshore wind with climate change or energy deficit was not seen as a politically realistic option. As a result, there was a growing understanding that the government was unlikely to finance the development of a large domestic market for offshore wind in Norway. However, reduced activity in the offshore petroleum industry created a new problem and a new opportunity. 
Because the petroleum industry is cyclical, many firms operating in the offshore petroleum industry need a strategy for diversification to meet situations of waning demand. Unsurprisingly, the industry is more attentive to this during periods of downturn:

In 2009, there was a major drop in oil prices with a decline in oil investments. There were layoffs in the oil service sector where the majority of employees in the oil industry work. This led to a discussion about how Norway could transfer the competence it had to new sectors and also a willingness to look at R\&D for the sector (Ellingsen 2013).

Firms in the offshore petroleum industry were increasingly looking for alternative projects. In 2009, the lack of orders in the offshore supply industry was a much debated topic in Parliament, and became a recognised problem by both the government and the political opposition. This problem was most prominent in the Verdal region of Norway where the cornerstone company Aker Verdal had to lay off workers. The solution of offshore wind that had emerged in the policy stream thus became an attractive opportunity for the industrial cluster in Verdal. The government therefore supported a diversification into offshore wind by providing funding for the development of a harbour that could accommodate offshore wind turbines, by financing the establishment of a wind energy cluster in the region, and by attracting GE Energy to invest in local turbine production company ScanWind.

The more explicit articulation of industry decline as a problem by both political and industry actors can also be observed in the way Vestavind Offshore developed its strategy for the Havsul offshore wind farm. To help attract attention from influential policy makers and the political elite, the offshore wind alternative was attached explicitly to the industrial problem as a solution to job losses and industrial decline:

The purpose of the Havsul project was to produce energy. The other stuff was about communication and how to argue that this should be given money. Energy shortage is not a hot enough topic in Norway to mobilize great political interest, but if you can say that this also contributes to tremendous industrial development on the west coast, because it would certainly have created many jobs, then it would be more interesting for a wider political audience (Lie Larsen 2013).

Summing up the period from 2005 to 2009, offshore wind as a solution developed at first rather independently through entrepreneurial activity and exogenous developments such as a growing international market. The idea of offshore wind was initially only to a very limited extent coupled as a policy solution to a particular problem. With changes in the political stream favouring offshore wind and problems related to climate change, energy deficiency and industrial decline all articulated at various points in this period, the potential for joining the streams of politics, policy and problems opened up. In the end, it was with the problem of industrial decline towards the end of this period that the most potent coupling occurred.

The description so far lends strength to the perspective provided by Mucciaroni (1992) in that the streams do not develop entirely independently. The initial attention in the political stream to offshore 
wind came as a result of the promising technology developments in the policy stream, as well as the early willingness of energy companies such as Statoil, Lyse Energi and Vestavind Offshore to invest in offshore wind. Further, the articulation of problems related to both climate change, industrial decline and energy deficit were all in various ways influenced by the developments in the political stream. Thus, we can see the opening of a window of opportunity as a result of both fortuitous timing and strategically based actions.

\subsection{The window closes (2010-2012)}

The success of offshore wind depends on bringing costs down through innovation and learning, which primarily takes place in firms. These firms need learning arenas not only to demonstrate technology, but to also foster further learning processes and build support for a technology (Kemp et al. 1998, p. 184). Still, the Norwegian industry lacked a domestic market that could provide such a learning arena (Hansen \& Steen 2011). The general innovation policy approach in Norway was based on R\&D incentives for technology development and a cost-efficiency principle guiding investment support for the more mature technologies (Bysveen 2013). This left a policy gap for bridging the "valley of death" facing offshore wind projects (Flataker 2013). In an attempt to better attach offshore wind to the problem of industrial decline, the offshore wind actors focused more on the need for government to assist the development of an industry through the establishment of demonstration projects, rather than subsidising production of electricity. The most noteworthy proposals for such demonstration projects were Demo Rogaland (Statoil, GE Energy and Lyse Energi) and Demo2020 (NOWITECH, NORCOWE, Arena NOW and Arena Mid-Norway). In particular, Demo2020 received support from both The Federation of Norwegian Industries and the Norwegian Confederation of Trade Unions (LO). Simultaneously, on a more general level, the need for government funding of offshore wind demonstration projects was repeatedly put forward by representatives from both government and opposition parties in Parliament in 2010. However, even though there was no real resistance against offshore wind within the government (Halvorsen 2014), the supporters of Demo2020 were unable to convert the apparent support into a favourable policy outcome in terms of funding for the project.

It is not possible to point to one single explanation to this outcome. Several respondents involved in the demonstration proposals pointed out that the proposals suffered from competition between different regions and industrial actors (Aamodt 2014; Strømmen Lycke 2013), and that competition between the two proposals damaged the entire process:

Instead of cooperating and being satisfied with that, people would say that it had to be Havsul or a different project. That is a little destructive for achieving political consensus. (...) To get the whole industry, the developer and the government to agree on a good model, that is difficult (Tande 2013).

This lack of collective action and a single proposal to the authorities shows that the offshore wind industry suffered from "weak networks” (Carlsson \& Jacobsson 1997). Poor interaction between 
organisations can lead to a lack of shared visions for future technology developments, which might hinder both research efforts and, perhaps more relevant in this context, investments in a technology (Woolthuis, Lankhuizen, \& Gilsing 2005).

Moreover, having already dealt with major internal conflicts over other climate and energy issues related to CCS investments at Mongstad, and lengthy negotiations over the introduction of a tradable green certificate scheme, there was little room left for the supporters of offshore wind inside the government to fight for government funding of Demo2020:

We had a major effort to solve the issue over natural gas with CCS at Mongstad, and we had to deal with the issue of tradable green certificates for years. It was not easy to ask for another couple of billion NOK when we had spent so much money on these other issues that the Prime Minister was opposed to (Sørensen 2014).

It should here be noted that because the CCS process was concluded in 2005 (Sørensen 2014), policies for the demonstration of offshore wind was in no direct competition with CCS (Halvorsen 2014). By contrast, the negotiations over the certificates took place in 2008 and 2009, during a period when there was considerable interest for offshore wind, and was the result of a long-standing pressure to introduce a policy instrument that promoted new clean energy production in Norway. However, because this scheme is a technology-neutral policy instrument that favours mature industries at the expense of the more expensive technologies (Bergek \& Jacobsson 2011), the scheme can be seen as a continuation of the dominant energy regime with little to be gained for the offshore wind industry. One respondent pointed out that no one positioned the certificate debate towards how the scheme could deliver to offshore wind (Holmås 2014). This can in some way be explained by poorly organised interests advocating technology specific policies at the time, and strong coalitions supporting cost-efficient energy policies (Gotaas 2014).

Finally, political actors are not unaffected by external pressure. It is therefore interesting to observe that none of the environmental organisations had offshore wind as a priority. Offshore wind also lacked an enduring policy entrepreneur that could sustain momentum over time. With only nine months at the MPE, Åslaug Haga was not given time to show the tenacity that was needed. Similarly, the Demo2020 initiative lacked a responsible person who could sustain a consistent effort over time (Frøysa 2013).

With a recognition that offshore wind could not be realised through the certificate scheme (Dale 2013; Lygre 2013), and the unsuccessful proposals for demonstration projects in 2010, much relied on whether Enova would be handed the opportunity to support large scale demonstration projects.

In March 2011 two influential changes in the political and the problem streams occurred within the space of two weeks. First, the government announced a new Minister of Petroleum and Energy, who supported considerably different policies than his predecessors (Ellingsen 2013). Shortly thereafter, 
Statoil announced a major oil discovery in the Barents Sea. The former event made the political stream less favourable to the solution of offshore wind. The latter event led to increased optimism in the O\&G supply industry, diminishing the problem of industry decline. A few months later, GE Energy announced the discontinuation of the production facility in Verdal, which sent a negative signal to the entire offshore wind industry in Norway. Even so, Vestavind Offshore remained optimistic, and made a range of attempts in 2011 and 2012 at establishing a dialogue with both the MPE and the Ministry of Trade and Industry. However, there was little political interest to meet with representatives from Vestavind Offshore (Ellingsen 2013). One of the respondents argued that Vestavind Offshore did not pay enough attention at an early stage to the issue of securing political backing for the financing of the project, and that once they did start to focus on this area it was too late and the opportunity was missed (Dirdal 2013). Another respondent pointed to insufficient knowledge and experience with working with policies for offshore wind within both the MPE and Enova (Lie Larsen 2013). Former minister Haga expressed similar views, stating that the MPE completely lacked competence in new renewable energy (Haga 2012, pp. 294-6). The Havsul project was also hampered by challenging seabed conditions (Strømmen Lycke 2013) and the overall complexity and costs of offshore wind turned out be higher than what had been anticipated a few years earlier (Engevik 2014; Gotaas 2014). Thus, the respondents point to what Kingdon would identify as a failure to meet the necessary criteria for the solution to be considered as a viable proposal (2011, p. 131).

After much uncertainty, it became clear in the summer of 2012 that Enova had not been granted the mandate to support Havsul or similar large-scale offshore wind projects (MPE 2012, pp. 168-71). For this reason, the board of Vestavind Offshore declared in December 2012 that they had given up on the Havsul project due to unfavourable framework conditions (Bergens Tidende 2012).

The period from 2010 to 2012 shows how advocates of offshore wind attempted to exploit the window of opportunity by lobbying for the public funding of large demonstration projects. Yet, the advocates were unable to exploit the opportunity due to unfavourable conditions in the political stream, the lack of a persistent policy entrepreneur and because offshore wind was not sufficiently developed as a solution. Policy windows rarely remain open for long (Kingdon 2011, p. 166), and in 2011 exogenous events and a ministerial change ultimately closed the policy window for offshore wind in Norway.

\section{Conclusions}

The point of departure for this paper has been an acknowledgement of the dependence of new renewable energy technologies on technology-specific policies. I have pointed out that while policy has been a central topic in many studies of renewable energy technologies and transition processes, the complexities of the policy process have often been underplayed. I have shown that an analysis of the development of streams of politics, solutions and problems can complement what we know about transition dynamics from the innovation literature. 
First, the agenda-setting model provides a precise framework to study the importance of the timing of events and developments at different levels. From a multilevel perspective, we can see that a window of opportunity opened up as exogenous events put pressure on the regime, whereas developments in the offshore wind industry placed it in a position to exploit these opportunities. Be that as it may, the findings in this paper show that the first problems of climate change and energy security did not provide sufficient conditions for the exploitation of this window of opportunity as offshore wind represented a climate and energy measure that fit poorly with the principles of cost-efficiency. Thus, we can say that offshore wind was attached to inappropriate problems (Kingdon 2011, p. 178).

However, exogenous events affecting the offshore petroleum industry gave rise to a new problem of industrial decline. To this problem, offshore wind was articulated as a more credible solution than to the problems of climate and energy. Nevertheless, this new coupling of problem and solution, which provided favourable conditions for change, did not materialize into ambitious policies for offshore wind. In this paper, I suggest that developments in the political stream have had a significant influence on this outcome.

Furthermore, offshore wind as a policy alternative failed to meet Kingdon's criteria related technical feasibility and anticipated costs (2011, pp. 131-9). To this, we can add that a lack of cooperation also undermined the potential for offshore wind as a solution. Through the lens of a technological innovation systems framework, this can be conceptualized as a system weakness in the form of weak networks that led to a weak legitimation function (Jacobsson \& Bergek 2011, p. 51).

A scrutiny of developments in the problem stream also shows how new petroleum discoveries resulted in increased activity levels in the offshore petroleum industry, which led firms to redeploy resources back to petroleum activities. Exogenous events that prompt windows to open may quickly go away (Kingdon 2011, p. 169). The timing of the petroleum discoveries influenced the direction of search by altering the expectations for offshore wind and the legitimacy for public policy. The significance of these events, which was beyond the influence of the actors related to offshore wind, thus exhibits some of the difficulties in managing niche protection (Shove \& Walker 2007).

Most significantly though, the case of offshore wind in Norway demonstrates how political conditions influence the development of new renewable energy technologies. I have therefore put forth that the main contribution of applying an agenda-setting model to the study of renewable energy technologies is that it allows for a detailed analysis of actors in the political stream. First, we have observed the way in which a ministerial change contributed towards placing offshore wind on the political agenda in a period when the coupling of streams was possible. Similarly, a new ministerial change four years later diminished the chances of the coupling of offshore wind with any articulated problem. Hence, even though we recognise the importance of developments at both the landscape- and niche levels, this 
study also points to the role of strategic political actors that operate at the regime level. In this way, whereas the multilevel perspective lets us observe that windows of opportunity occur, concepts from an agenda-setting model allows us to explore in more detail how and why windows open and close.

Second, the findings in this paper remind us that governments consist of a heterogeneous mix of actors with often competing interests (Smith 1993). Conflicts within the government over issues related to natural gas fired power plants, and the introduction of a tradable certificate system, led to the prioritization of these issues. In contrast, offshore wind did not have the capacity to solve conflicts inside the government. Consequently, building alliances with actors inside the government and with environmental organisations became difficult for offshore wind advocates. An implication of these observations is that we need to reflect more on how we can include the different interests of government actors, as well as their influences on policy, in the study of sustainable transitions.

On a related note, the green certificates process uncovers a weakness in the agenda-setting model in that it is less suitable for analyzing how groups of interests compete over policy outcomes. The TIS does recognize the role of networks in the policy process. However, the emphasis tends to be placed on the effects of networks on system performance or how policy might strengthen certain networks, rather than on how the balance of power in networks evolves and how the structure of the networks changes. A network approach such as the advocacy coalition framework could be a useful alternative for studying this particular aspect of the development of offshore wind in Norway.

Lastly, and in an attempt to end on a positive note, Hay (2002, p. 133) remarks that although strategic action can help yield a minimal transformation of the context, it can yield strategic learning on the part of the actors involved, thereby enhancing an awareness of structures and providing the basis for a subsequent strategy that can be formulated for further contextual change. Provided that there is a degree of continuity among the actors involved in offshore wind, lessons from the experiences described in this paper could provide these actors with improved capabilities to influence the regime in the future. With increasing uncertainties related to the issues of "unburnable carbon" and activity levels in the offshore petroleum supply industry, this could become relevant sooner rather than later.

\section{Acknowledgements}

I want to thank the editor and two anonymous reviewers for thoughtful and constructive comments on previous versions of this paper. I am further grateful to Sjur Kasa, Olav Wicken and Jens Hanson for comments on early drafts. 


\section{References}

Aamodt, A. Former CEO, Lyse Produksjon AS, Phone, 20 March 2014.

Alstadheim, K. B., \& Stoltenberg, J. (2010). Klimaparadokset: Jens Stoltenberg om vår tids største utfordring. Oslo: Aschehoug.

Avelino, F., \& Rotmans, J. (2009). Power in Transition: An Interdisciplinary Framework to Study Power in Relation to Structural Change. European Journal of Social Theory, 12(4), 543-69.

Bergek, A., \& Jacobsson, S. (2011). Fremmer grønne sertifikater ny teknologi? In J. Hanson, S. Kasa \& O. Wicken (Eds.), Energirikdommens paradokser: innovasjon som klimapolitikk og nœringsutvikling (pp. 82-102). Oslo: Universitetsforlaget.

Bergens Tidende (2011, October 7). Priskutt for havvind.

Bergens Tidende (2012, December 5). Tar stort tap på vindkraft.

Borrás, S., \& Edler, J. (2013). The Governance of Change in Socio-Technical and Innovation Systems: Some Pillars for Theory-Building. Paper presented at Eu-SPRI Madrid 2013.

Bysveen, S. Executive Vice President Corporate Development, Statkraft. Former Director, Energy Norway., Lysaker, 14 May 2013.

Carlsson, B., \& Jacobsson, S. (1997). In Search of Useful Public Policies — Key Lessons and Issues for Policy Makers. In B. Carlsson (Ed.), Technological Systems and Industrial Dynamics (Vol. 10, pp. 299-315): Springer US.

Dale, J. Business developer, Scatec, Oslo, 2 April 2013.

Dirdal, H. Harald Dirdal, Owner, Havgul, Oslo, 15 August 2013.

Ellingsen, A. G. Former CEO Vestavind Offshore, Kristiansand, 3 April 2013.

Elzen, B., Geels, F. W., Leeuwis, C., \& van Mierlo, B. (2011). Normative contestation in transitions 'in the making': Animal welfare concerns and system innovation in pig husbandry. Research Policy, 40(2), 263-75.

Energirådet (2008). Vindkraft offshore - industrielle muligheter for Norge.

Engevik, T. Director of wind, Aibel. Former CEO, Vestavind Offshore, Phone, 14 February 2014.

EWEA (2013). Deep Water - The next step for offshore wind energy, European Wind Energy Association.

Flanagan, K., Uyarra, E., \& Laranja, M. (2011). Reconceptualising the 'policy mix' for innovation. Research Policy, 40(5), 702-13.

Flataker, O. Former Head of Climate, Industry and Technology Department, Ministry of Petroleum and Energy, Oslo, 6 June 2013.

Frøysa, K. G. Director, NORCOWE, Oslo, 6 March 2013.

Geels, F. W. (2011). The multi-level perspective on sustainability transitions: Responses to seven criticisms. Environmental Innovation and Societal Transitions, 1(1), 24-40.

Geels, F. W., \& Schot, J. (2007). Typology of sociotechnical transition pathways. Research Policy, 36(3), 399-417. 
George, A. L., \& Bennett, A. (2005). Case studies and theory development in the social sciences. Cambridge, Mass.: MIT Press.

Gotaas, S. CTO Kongsberg Group. Former SVP Statkraft, Lysaker, 12 June 2014.

Haga, Å. (2012). Rødgrønn: slik jeg ser det [Red-green: the way I see it]. Oslo: Schibsted.

Halvorsen, K. Former leader of Socialist Left Party (1997-2012), Minister of Finance (2005-2009), Oslo, 18 March 2014.

Hannigan, J. A. (1995). Environmental sociology: a social constructionist perspective. London: Routledge.

Hansen, G. H., \& Steen, M. (2011). Vindkraft til havs: teknologi- og industriutvikling fra et norsk bedriftsperspektiv [Offshore wind power: technological and industrial development from a Norwegian business perspective], Centre for Sustainable Energy Studies.

Hanson, J. (2013). Dynamics of Innovation Systems for Renewable Energy Technology: The Role of Post-introduction Improvements. PhD thesis, University of Oslo.

Hanson, J., Kasa, S., \& Wicken, O. (2011). Politikk for den store transformasjonen [Policies for the great transformation]. In J. Hanson, S. Kasa \& O. Wicken (Eds.), Energirikdommens paradokser: Innovasjon som klimapolitikk og næringsutvikling. Oslo: Universitetsforlaget.

Hay, C. (2002). Political analysis: a critical introduction. Basingstoke: Palgrave.

Hekkert, M. P., Suurs, R. A. A., Negro, S. O., Kuhlmann, S., \& Smits, R. E. H. M. (2007). Functions of innovation systems: A new approach for analysing technological change. Technological Forecasting and Social Change, 74(4), 413-32.

Hill, M. (2013). The public policy process. Harlow: Pearson.

Hjørnegård, S. Director renewable energy, climate and environment, Energy Norway. Former political advisor and State Secretary, Ministry of Petroleum and Energy (2008-2011), Oslo, 4 June 2014.

Holmås, H. Socialist Left Party MP, Oslo, 25 April 2014.

Hovi, J., Underdal, A., \& Ward, H. (2011). Potential Contributions of Political Science to Environmental Economics. Environmental and Resource Economics, 48(3), 391-411.

Jacobsson, S., \& Bergek, A. (2011). Innovation system analyses and sustainability transitions: Contributions and suggestions for research. Environmental Innovation and Societal Transitions, 1(1), 41-57.

Jacobsson, S., \& Lauber, V. (2006). The politics and policy of energy system transformation explaining the German diffusion of renewable energy technology. Energy Policy, 34(3), 25676.

Kemp, R., Schot, J., \& Hoogma, R. (1998). Regime shifts to sustainability through processes of niche formation: The approach of strategic niche management. Technology Analysis \& Strategic Management, 10(2), 175-98. 
Kern, F. (2010). The politics of governing 'system innovations' towards sustainable electricity systems.

Doctoral thesis, University of Sussex.

Kern, F., Smith, A., Raven, R., \& Verhees, B. (2013). The Politics of Low Carbon Transitions Protected niches, actor networks, narratives and changing context. Paper presented at IGov Workshop, London, 2013.

Kern, F., Smith, A., Shaw, C., Raven, R., \& Verhees, B. (2014). From laggard to leader: Explaining offshore wind developments in the UK. Energy Policy, 69(0), 635-46.

Kingdon, J. W. (1984). Agendas, alternatives, and public policies. Boston: Little, Brown and Co.

Kingdon, J. W. (2011). Agendas, alternatives, and public policies (Updated second edition ed.). New York: Longman.

Lie Larsen, T. Communication Advisor, JKL, Oslo, 14 August 2013.

Lygre, A. Director, Arena NOW, Bergen, 8 March 2013.

Markard, J., \& Truffer, B. (2008). Technological innovation systems and the multi-level perspective: Towards an integrated framework. Research Policy, 37(4), 596-615.

Marsh, D., \& Rhodes, R. A. W. (1992). Policy networks in British government. Oxford: Clarendon Press.

Meadowcroft, J. (2011). Engaging with the politics of sustainability transitions. Environmental Innovation and Societal Transitions, 1(1), 70-5.

MPE (2012). Proposition to the Parliament for budget year 2013. Ministry of Petroleum and Energy Prop. 1 S 2012-2013.

Mucciaroni, G. (1992). The Garbage Can Model \& the Study of Policy Making: A Critique. Polity, 24(3), 459-82.

Pettigrew, A. M. (1997). What is a processual analysis? Scandinavian Journal of Management, 13(4), 337-48.

Sabatier, P. A. (1991). Toward Better Theories of the Policy Process. PS: Political Science and Politics, 24(2), 147-56.

Sabatier, P. A., \& Jenkins-Smith, H. C. (1993). Policy change and learning: an advocacy coalition approach. Boulder, Colo: Westview Press.

Sanden, B. A., \& Azar, C. (2005). Near-term technology policies for long-term climate targets economy wide versus technology specific approaches. Energy Policy, 33(12), 1557-76.

Shove, E., \& Walker, G. (2007). CAUTION! Transitions ahead: politics, practice, and sustainable transition management. Environment and Planning A, 39(4), 763-70.

Smith, A., \& Raven, R. (2012). What is protective space? Reconsidering niches in transitions to sustainability. Research Policy, 41(6), 1025-36.

Smith, A., Stirling, A., \& Berkhout, F. (2005). The governance of sustainable socio-technical transitions. Research Policy, 34(10), 1491-510. 
Smith, A., Voß, J.-P., \& Grin, J. (2010). Innovation studies and sustainability transitions: The allure of the multi-level perspective and its challenges. Research Policy, 39(4), 435-48.

Smith, K. E. (2007). Health inequalities in Scotland and England: the contrasting journeys of ideas from research into policy. Social Science \& Medicine, 64(7), 1438-49.

Smith, M. J. (1993). Pressure, power and policy: state autonomy and policy networks in Britain and the United States. New York: Harvester Wheatsheaf.

Steen, M., \& Hansen, G. H. (2013). Same Sea, Different Ponds: Cross-Sectorial Knowledge Spillovers in the North Sea. European Planning Studies, 1-20.

Stortinget (2006). Interpellation from Representative Peter Løvik to the Minister of Petroleum and Energy. Minutes from Parliament, 16 February 2006.

Stortinget (2007). Representative Proposal. Dokument nr. 8:67 (2006-2007)

Stortinget (2008). Recommendation from the Standing Committee on Energy and the Environment. Innst. S. nr. 147 (2007-2008).

Strømmen Lycke, A. Former Vice President Wind Power, Statoil, Oslo, 29 April 2013.

Sunnmørsposten (2009, November 16). Mer enn flau bris?

Sørensen, H. Former State Secretary, Ministry of the Environment (2007-2012), Oslo, 18 March 2014.

Tande, J. O. Director, NOWITECH, Phone, 9 August 2013.

Thies, C. G. (2002). A Pragmatic Guide to Qualitative Historical Analysis in the Study of International Relations. International Studies Perspectives, 3(4), 351-72.

Unruh, G. C. (2000). Understanding carbon lock-in. Energy Policy, 28(12), 817-30.

Weber, K. M., \& Rohracher, H. (2012). Legitimizing research, technology and innovation policies for transformative change: Combining insights from innovation systems and multi-level perspective in a comprehensive 'failures' framework. Research Policy, 41(6), 1037-47.

Woolthuis, R. K., Lankhuizen, M., \& Gilsing, V. (2005). A system failure framework for innovation policy design. Technovation, 25(6), 609-19. 